Earth \& Environment | James Dyer \& Raymond Desjardins

\section{Protein as a Unifying Metric for Carbon Footprinting Livestock}

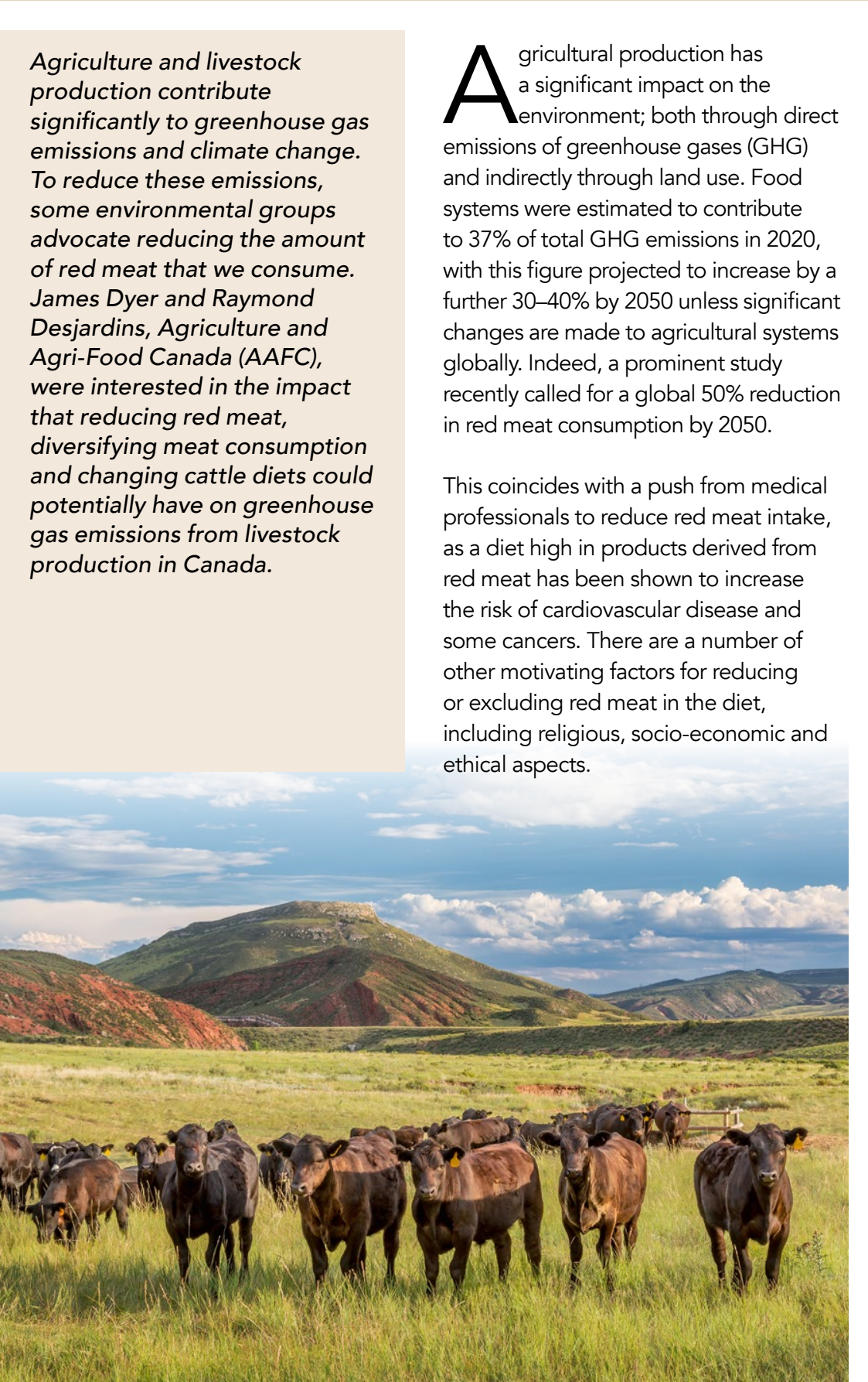

Agencies in Canada are investigating ways to reduce the carbon footprint livestock production. As part of the Carging hat a more diverse range of protein sources, including non-animal sources such as pulses and legumes, should be incorporated in the diet. This would result in reduced red meat consumption by Canadians.

Given the complex interplay between human diet, land use and climate change, how a potential reduction in the amount of red meat eaten would impact the dian livestock is poorly understood.

\section{A COMMON DENOMINATOR} Much of the work done to minimise the ivestock carbon footprint in Canada bef, pork, daivy pouttry and she Hel, pork, daly, pouly dind sheep. and production systems for these industries, it has been difficult to directly compare their carbon footprints, highlighting the need for a common denominator. The use of a common food constituent, edible protein, represents a comparable measurement
that can be derived from each livestock comm in 2010 by James Dyer and Dr Raymond Desjardins, Agriculture and Agri-Food Canada, and the term 'GHG-protein indicator' was coined. Since 2010, this GHG-protein indicator has undergone wide variety of applications in Canada where it has been used to comp Wh emissions and the protein derived from livestock in a number of made the indicator value as reliable as possible by incorporating the life cycles or the difcrent types of livestock Canada. Their more recent studies are, therefore, supported by previous robust, peer-reviewed literature.

One potential disadvantage of the GHGprotein indicator is that it only considers protein, not the fats and carbohydrates that are also found in meats, meaning that the full nutritional picture is not easily considered. Consequently, Dyer and Desjardins point out that the GHGprotein indicator should be just one

\section{LIVESTOCK AND}

REENHOUSE GAS EMISSIONS Many medo systems. However these are often specificly desiged for a certain type of livestock, agricultural conditions and computation assumptions, meaning that they can neither be compared no applied to a wide variety of scenarios. This limitation made studying the interactions among the livestock industries a major challenge.

Using the GHG-protein indicator allowed Dyer and Desjardins to investigate the impact that a reduction in red meat consumption would have on

The researchers established the mount of meat that would need to be produced in order to meet current levels used nine different scenaios, taking into account factors such as livestock type, production system required, and the crops needed to provide feed for the livestock. While only a simulation rather than an analysis of real data, the results predict the general trend in $\mathrm{GHG}$ emissions if red meat consumption was reduced from the level at which it is now consumed to the minimum intake recommended by medical professionals (between $16 \mathrm{~kg}$ and $28 \mathrm{~kg}$ of boneless meat per year, depending on the type of meat).

Their simulation assumed that a major expansion in broiler production would be needed to meet the current protein
GHG-protein indicator factors for livestock products in Canada, in 200

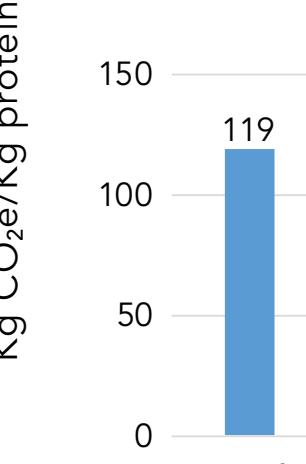

$\begin{array}{llll}32 & 25 & 22\end{array}$

Fig.1 Carbon foo
Canada, in 2001 .

Beef

Milk Pork Broilers Eggs Lamb

Canada, this equated to meeting the cur GHO peryear, which

The findings of a second paper suggested that moving from ruminant to non-ruminant meat production could be as effective as an overall, medically motivated reduction in red meat

o lower emissions further than the medical scenario. Another scenario defined grass-fed beef as slaughter cattle until slaughter, instead of the grain-fed slaughter cattle which were fattened for market with feed grains. While the difference between these two beef production systems had some effect on the carbon footprint estimates, it was only

If consumers ate less red meat and diversified their meat choices, they could significantly reduce GHG emissions from agriculture.

consumption when it comes to lowering GHGerdins and production scenarios, combined with the average medical recommendation to reduce red meat consumption by about $24 \%$, would lead to significant decreases in $\mathrm{GHG}$ emissions from livestock production.

The first production scenario, including a 50:50 split between beef and pork, and grain-fed beef (the current feedlot industry), could reduce GHG emissions from Canadian agriculture by around $4 \mathrm{Mt}$ $\mathrm{CO}_{2}$ e. Modifying this scenario to a $25: 75$ beef-pork split would make this reduction around $9 \mathrm{Mt} \mathrm{CO}_{2} \mathrm{e}$. From this beef-pork split the authors concluded that an overal with an in the beef industry, combined with an increase in non-ruminant livestock
(broilers and pork), would be required half of the magnitude of the difference between ruminan
meat production.

In addition, they identified that a large proportion of land used to grow perennial forage for cattle was superfluous to both non-ruminant livestock production and grain-based feedlot beef production. This finding had a profound implication for comparing arbon footprint calculations. Since nonruminant livestock and feedlot beef cattle can both produce the same amount of protein as grass-fed beef catle without as much land seeded to perennial forage, the additional land for grass-fed beef would not need to be cultivated for either could still be sequalcrops, and carbon could stil be sequestered under that land through any other non-agricultural 
Therefore, that sequestered carbon can be discounted from the comparative three production systems.

Protein (Pn) and Red Meat (RM)

Boundary Conditions

25

\section{NEXT STEPS}

The use of animal protein to compare gricultural emissions allows consumers easily understand how their protein The results of the work done by these Canadian scientists essentially quantifi how much lower GHG emissions from pigs and poultry livestock systems are than those from ruminant livestock such as cattle, sheep and goats. Despite the enteric methane emissions from cattle and their slow rates of growth and reproduction compared to nonfuninants, alising catte on perennial forage can sequester atmospheric $\mathrm{CO}_{2}$ Desizrdins tumed their Dytron to use to help resolve this trade-off.

In their simulation, Dyer and Desjardins made the land used for perennial

forage interchangeable with annua

crop production, meaning that it is not exclusively used to produce red meat. But unimproved grazing land would not be interchangeable with annual crop production since it can only be used for grazing. It is also essential to consider other ways in which land can be used; for example, how much low-quality land is really required for grazing animals, and the habitat to support wildlife?

Furthermore, land freed up from a Froduction harnessed for biofuel crops (en

crops which avoid the burning offoss carbon), or edible grains, pulses and cooking oils. Overall, livestock species should not be considered in isolation, and the Canadian livestock industry must be considered as a whole, rather than as separate enterprises.

There are further interesting considerations which arise from this work, inclualing the question of whether we should cut out meat from our diets altogether. Since most plant proteins end not to provide all of the nine essential amino acids that the human

important as protein quantity. These then there would also be a decrease

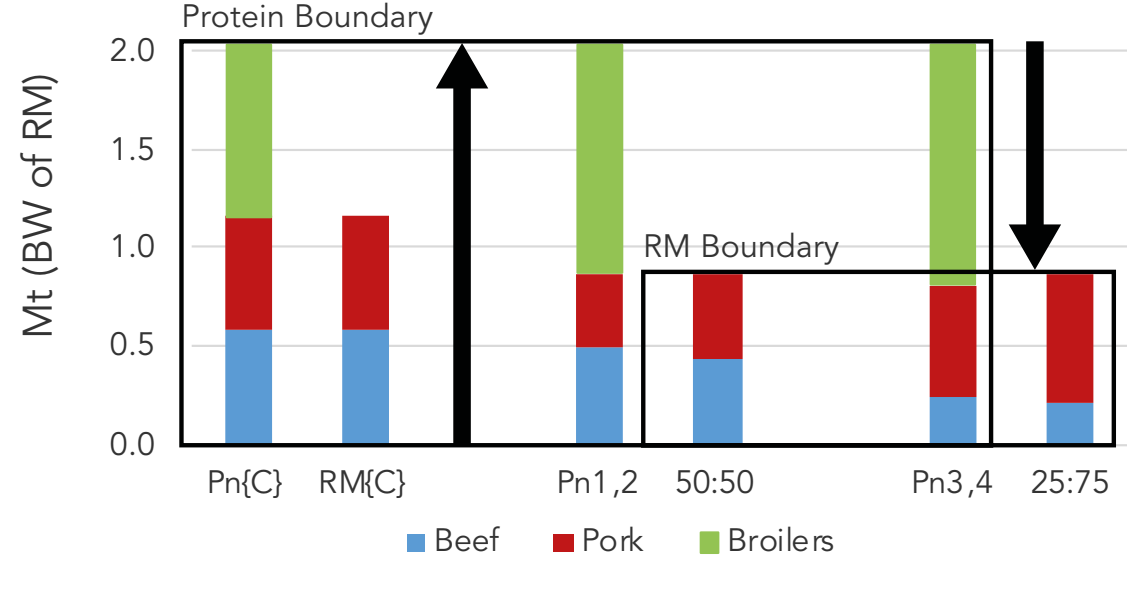
recommendation of Red Meat (RM). An upper boundary condition (larger box) was based on
maintaining total protein Consumption (C) at the amount of Protein (Pn) that Canadians consumed from beef, pork and broilers in 2017 . This boundary condition required expanded broiler consumption. meat. Both boundary conditions apply to two pairs of simulations. The first pair assumed a 50:50 split between beef and pork. The second pair assumed a 25.75 beef-pork split. Within each pair of

essential amino acids explain why meat,

They suggest that there is still a eggs and dairy products, along with ___ place for grass-fed beef, but that some pulses and legumes, are such producers should consider using popular food choices with consumers. pork and chicken, further supporting $\begin{array}{ll}\text { boundary condition, Dyer and Desjardins } & \text { Canada Food Guide about the } \\ \text { posed the broader question of how } & \text { diversification of protein sources. }\end{array}$ posed the broader question of how

The GHG-protein indicator results can
show consumers and producers the show consumers and producified meat choices on GHG emissions.

much animal protein humanity needs to consume, considering land used beyon this demand as an inefficient use of resources. If not used to rear ruminant livestock, this land could be converted back to its natural state, encouraging biodiversity and further carbon sequestration. Dyer and Desjardins highlight that if Canadians followed the red meat guidelines provided by health and medical practitioners, in GHG emissions from livestock production. However, his is hugely epentan
Fig. 2 Two boundary conditions set the limits of the livestock $G H G$ emissions simulation. A lower
boundary condition (smaller box) was based on limiting beef and pork consumption to the medica simulations are two diet options for finishing slaughter
emissions, neither option affected Pnor more of their feed grains to produce
Moreover, the GHG-protein indicator can be used to inform consumers and meat consumption on GHG levels

Ultimately, a balance between the amount of livestock needed to meet demand and the amount of land allocated to these systems needs to be optimised. This would provide highquality protein for human consumption GHG emissions to conthution of GHG emissions to climate change. The tool in this optimisation process. producers about the impact of red

\section{Behind the Research}

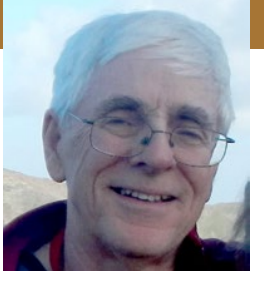

James A.

Dyer

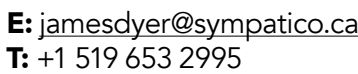

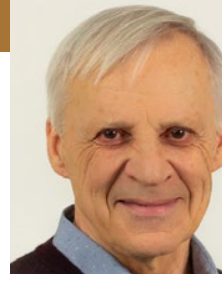

Raymond L. Desjardins

E: ray.desjardins@canada.ca en/profile/d-raymond-desjardins

Research Objectives

Dyer and Desjardins have studied the potential impact of reducing and diversifying meat consumption on greenhouse gas (GHG) missions from livestock production in Canada.

Detail

122 Hexam Street

Cambridge

Ontario

Canada

$\mathrm{N} 3 \mathrm{H} 329$

Raymond Desjardins

960 Carling Aven

Ottawa
Canada

K1A 0C6

James A. Dyer received an MSc from the University of Guelph in 1975. He worked in Canada as an agro-climatologist and agro-environmental officer unt 1997. Since then, Dyer specialised in researcher He has published 67 reviact journal articles, 13 book chapters and dozens of technical reports.

Raymond L. Desjardins, CM, FRSC, PhD is a Canadian agricultural meteorologist

\section{References} (2020). Impact of recommended red meat consumption production. Jornal of Cleaner Production 266 , 121785. Available at: https://www.doi.org/10 1016 jclepro.2020.121785

Dyer, J. A., Desjardins, R. L., Worth, D. E., \& Vergé, X. P. C. (2020). Potential Role for Consumers to Reduce Canadian Sources Sustainability 12(13) 5466 Available at Pro https://www.doi.org/10.3390/su12135466

$\mathrm{N}^{\mathrm{k}} \mathrm{m} \quad$ Agriculture and Agri-Food Canada
Dyer, J. A., Worth, D. E., Vergé, X. P. C., \& Desjardins, R. L. who has worked on greenhouse gas whes issues related to agriculture for more than 55 years. He Research and Development Centre of A Science and Technology Branch of Agriculture and Agri-Food Canada

Funding

The Science and Technology Branch of Agriculture and Agri-Food Canada

\section{Personal Response}

How could the research findings help minimise climate

II These findings show the potential value of a GHGprotein indicator as a common denominator for reporting the carbon footprint of livestock products. Canadian the sustainability of their diversified meat promote consumers. In addition, livestock producer groups could their production practices. This work adds to the body of knowledge that can be used to make informed decisions
from field to fork. apply these indicator values when assessing the impacts of

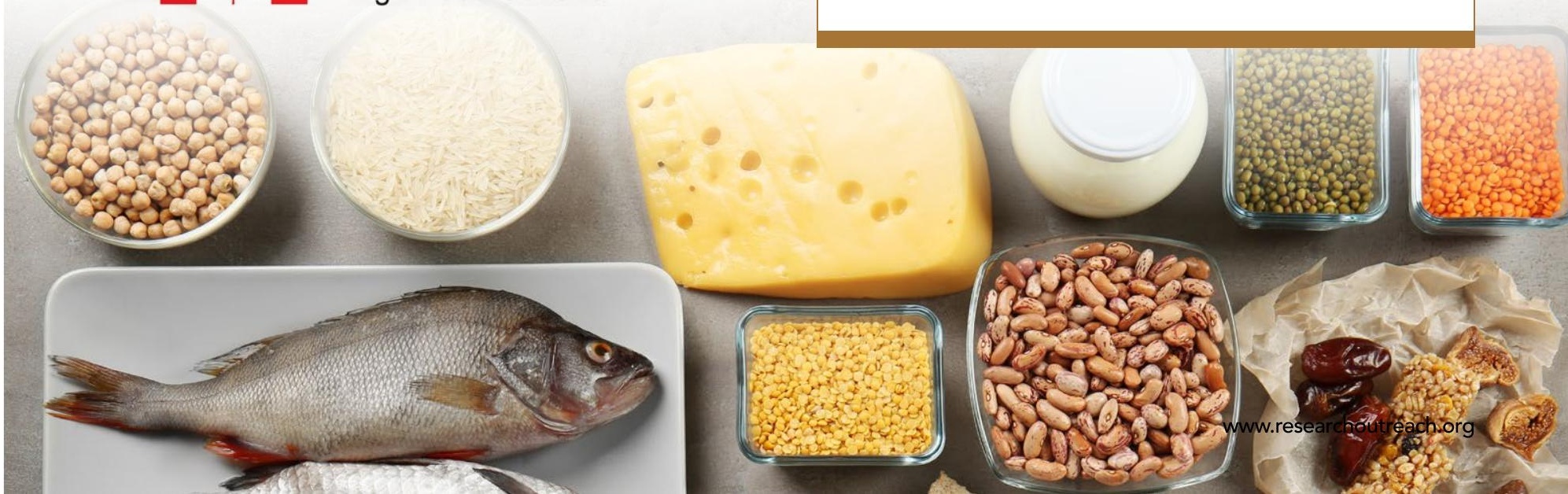

